\title{
Morfometría del cerdo de traspatio en áreas rurales de México
}

\section{Morphometry of native pigs in rural areas of Mexico}

\author{
Guillermo Martínez Velázqueza, Sergio Iván Román Ponceb, Alejandra Vélez Izquierdob, \\ Eduardo Cabrera Torresc, Antonio Cantú Covarrubiasd, Lino De la Cruz Colíne, \\ Marina Durán Aguilarf, J orge Alonso Maldonado Jaquezg, Fernando Edgar Martínez Silvab, \\ Ángel Ríos Utrerah, Vicente Eliezer Vega Murilloh, Felipe de Jesús Ruiz Lópezb
}

\begin{abstract}
RESUMEN
Para caracterizar a las poblaciones del cerdo Pelón Mexicano (PPM), cerdo Cuino (PCU) y cerdos cruzados (PCI) se analizó información de 241 entrevistas realizadas durante 2013. Las variables analizadas fueron: peso corporal (Peco), longitud de cabeza (Loca), longitud del cuerpo (Locu), circunferencia del pecho (Circu), altura a la cruz (Acruz), ancho de pelvis (Anpe), número de pezones (Nupe), pelo denso o escaso (Cape), presencia o ausencia de colmillos (Colm), hocico corto o largo (Hoc), orejas erguidas o no erguidas (Posio), temperamento tranquilo o inquieto (Tem), índice de proporcionalidad (IP), índice corporal (IC) e índice de peso relativo (IPR). Los datos se analizaron con GLM y GENMOD del SAS. Los modelos estadísticos incluyeron Estado y Población. Población influyó $(P<0.05)$ Peco, Locu, Circu, Acruz, Cape, Colm, Tem IP, IC e IPR. Los coeficientes de variación (CV) mostraron a Peco y Anpe como las características con menor y mayor variación (18.8 y $27.8 \%$ ). Para IP, IC e IPR los CV fueron $13.0,14.6$ y $45.8 \%$. Las medias de cuadrados mínimos para PPM, PCU y PCl fueron 48.06 $\pm 6.17 a, 35.93 \pm 3.04^{b}$ y $61.11 \pm 7.42^{a} \mathrm{~kg}(P e c 0)$; $77.81 \pm 3.65^{\mathrm{ab}}, 69.56 \pm 2.02^{\mathrm{a}}$ y $88.52 \pm 4.93^{\mathrm{b}} \mathrm{cm}$ (Locu); $80.55 \pm 3.98^{\mathrm{ab}}, 71.72 \pm 2.20^{\mathrm{a}}$ y $93.23 \pm 5.37^{\mathrm{b}} \mathrm{cm}($ Circu);

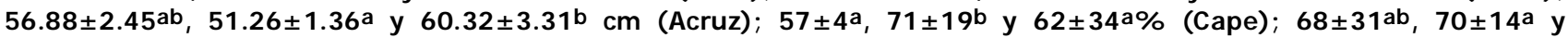
$61 \pm 27^{b} \%$ (Colm); $65 \pm 30^{a}, 56 \pm 12^{b}$ y $62 \pm 3^{a} \%$ (Tem). PPM y PCl fueron similares en morfometría pero diferentes de PCU. La población PCU mostró menor peso, menor talla y temperamento más inquieto. Caracterizar a estas poblaciones es importante para diseñar estrategias para su conservación y uso eficiente.
\end{abstract}

PALABRAS CLAVE: Morfometría, Cerdos criollos, Traspatio.

\begin{abstract}
Data from 241 interviews collected in 2013 was analyzed to characterize populations of pigs (Mexican Hairless Pig (MH), Cuino Pig (CU) and Crossbred Pig (UD)). Variables were body weight (BW), head length (HL), body length (BL), thoracic perimeter (CG), height at withers (HW), croup width (RW), number of nipples (TC), dense or sparse hair (HD), presence or absence of tusks (TU), short or long snout (ST), upright or floppy ears (ER), calm or restless temperament (TM), proportionality index (PI), body index (BI) and relative weight index (RWI). Analyses were carried out with GLM and GENMOD of SAS. Models included state and population. Population was significant (P<0.05) for BW, BL, CG, HW, RW, TU, TM, PI, BI and RWI. Coefficients of variation (VC) showed the minor and major values for BW (18.8\%) and CG (27.8\%). VC were 13.0, 14.6 and $45.8 \%$ for PI, BI and RWI. Least squares means for MH, CU and UD were: $48.06 \pm 6.17 \mathrm{a}, 35.93 \pm 3.04^{\mathrm{b}}$ and $61.11 \pm 7.42^{\mathrm{a}} \mathrm{kg}(\mathrm{BW}) ; 77.81 \pm 3.65^{\mathrm{ab}}, 69.56 \pm 2.02^{\mathrm{a}}$ and $88.52 \pm 4.93^{\mathrm{b}}$ $\mathrm{cm}$ (BL); 80.55 $\pm 3.98 \mathrm{ab}, 71.72 \pm 2.20^{\mathrm{a}}$ and $93.23 \pm 5.37^{\mathrm{b}} \mathrm{cm}$ (CG); $56.88 \pm 2.45 \mathrm{ab}, 51.26 \pm 1.36 \mathrm{a}$ and $60.32 \pm 3.31 \mathrm{~b} \mathrm{~cm}$

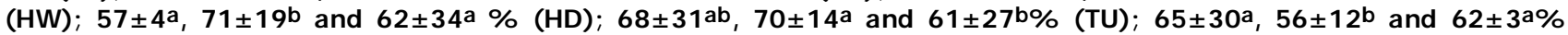
(TM). The MH and UD populations were similar in morphometry and different from the CU population. The CU population showed lower weight, smaller size and calmer temperament. The characterization of these populations is important for designing strategies for their conservation and efficient use.
\end{abstract}

KEY WORDS: Morphometry, Creoles, Native pigs.

Recibido el 12 de febrero de 2016. Aceptado el 1 de marzo de 2016.

a Instituto Nacional de Investigaciones Forestales, Agrícolas y Pecuarias (INIFAP). Campo Experimental Santiago Ixcuintla. Km. 6 Entronque Carret. Internacional México-Nogales. Santiago Ixcuintla, Nayarit C.P. 63300. martinez.guillermo@inifap.gob.mx Correspondencia al primer autor. b Centro Nacional de Investigación Disciplinaria en Fisiología y Mejoramiento Animal, INIFAP. c Campo Experimental Chetumal; CIRSE, INIFAP. d Sitio Experimental Aldama, CIRNE, INIFAP. e Campo Experimental Valle de México, CIRCE, INIFAP. $\mathbf{f}$ Facultad de Estudios Superiores Cuautitlán; UNAM. g Campo Experimental La Laguna, CIRNOC, INIFAP. h Campo Experimental La Posta, CIRGOC, INIFAP. México. 


\section{INTRODUCCIÓN}

En la porcicultura rural de México o porcicultura de traspatio se utilizan cerdos que se mantienen en sistemas de manejo de bajos insumos, en los que se aprovecha la rusticidad y los bajos requerimientos nutricionales que caracterizan a estas poblaciones. En las comunidades rurales en las que estos animales se desarrollan su alimentación consiste primordialmente de raíces, tubérculos, frutas, subproductos agrícolas y desperdicios de cocina $(1,2)$. Cabe señalar que la porcicultura de traspatio en México es una actividad importante que contribuye a la economía familiar y al consumo de proteína animal de los habitantes de comunidades rurales marginadas.

Adicionalmente, la importancia de las poblaciones locales de cerdos reside en que algunas de éstas pueden ser reservorios de variación genética útil como fuente de nuevos alelos para las poblaciones comerciales de cerdos(3). De lo anterior se reconoce la importancia de caracterizar fenotípica y genéticamente a las poblaciones locales de cerdos considerándose que entre las distintas alternativas que existen para la caracterización, y que son complementarias, la caracterización morfométrica es un paso básico para el uso eficiente de estos recursos genéticos. Así, diferentes estudios han sido publicados sobre la caracterización morfométrica de cerdos criollos evaluando, entre otras, características asociadas al crecimiento y al comportamiento reproductivo de estas poblaciones en diferentes sistemas de producción $(3,4,5)$.

Por lo anterior y considerando la importancia de la porcicultura de traspatio en el país, el presente estudio se plantea como una contribución a la caracterización morfométrica, cualitativa y cuantitativa, de las poblaciones de cerdos ubicadas en las comunidades rurales de México.

\section{MATERIAL Y MÉTODOS}

El estudio se realizó durante el año 2013 en 18 estados de la República Mexicana. La

\section{INTRODUCTION}

Rural, or backyard, pig farming in Mexico involves pigs raised in low-input management systems which take advantage of the rusticity and low nutritional requirements typical of these pig populations. In rural communities in Mexico, pig diets consist largely of roots, tubers, fruit, agricultural byproducts and kitchen waste $(1,2)$. Growing pigs is important for rural families because it provides animal protein and extra income.

Local rural pig populations can also function as reservoirs of genetic variation that can generate new alleles with potential applications in commercial pigs(3). It is therefore important to phenotypically and genetically characterize these populations. Morphometric characterization is a vital first step towards efficient use of genetic resources. Studies have been done of morphometric variables in backyard pigs focusing on traits associated with growth and reproductive behavior in pigs in different production systems $(3,4,5)$.

The present study objective was the qualitative and quantitative morphometric characterization of backyard pig populations located in rural communities of Mexico.

\section{MATERIAL AND METHODS}

In 2013, 241 surveys were applied to backyard pig owners in rural communities in 18 states in Mexico: Chihuahua, Coahuila, Durango and Zacatecas (arid and semiarid regions, $n=45$ ); Colima, Guerrero, Nayarit and Oaxaca (dry tropical region, $\mathrm{n}=71$ ); Campeche, Chiapas, Quintana Roo, Tabasco, Veracruz and Yucatan (humid tropical region, $\mathrm{n}=88$ ); and Mexico, Hidalgo, Jalisco and Queretaro (temperate region, $n=37$ ).

Sample size was calculated using the formula recommended by the $F A O(6): n=(z / m)^{2} p(1-p)$; where $z$ is 1.64 for a $90 \%$ confidence level, $\mathrm{m}$ is the margin of error $(0.05= \pm 5 \%)$, and $p$ 
información se obtuvo mediante 241 encuestas aplicadas a propietarios de cerdos de traspatio ubicados en comunidades rurales de los estados de Chihuahua, Coahuila, Durango y Zacatecas (regiones árida y semiárida, $\mathrm{n}=45$ ), de los estados de Colima, Guerrero, Nayarit y Oaxaca (región de trópico seco, $\mathrm{n}=71$ ), de los estados de Campeche, Chiapas, Quintana Roo, Tabasco, Veracruz y Yucatán (región del trópico húmedo, $\mathrm{n}=88$ ) y de los estados de México, Hidalgo, Jalisco y Querétaro (región templada, $n=37$ ).

El tamaño de muestra se determinó con la fórmula recomendada por la $\mathrm{FAO}$ (6) de acuerdo a lo siguiente: $n=(z / m)^{2} p(1-p) ; z$ es el valor de $z$ (1.64 para $90 \%$ de nivel de confianza), $m$ es el margen de error $(0.05= \pm 5 \%)$, y $p$ es el valor estimado de la proporción de la muestra que responderán a la encuesta en el mismo sentido, que para este caso se consideró de 0.45. La elección de los encuestados fue con la aplicación del método no probabilístico de bola de nieve, con el cual se identificó a propietarios de cerdos de traspatio, y con la información del primer productor se encuestó al siguiente y así sucesivamente hasta completar el tamaño de muestra estimado(7). El mismo día de la entrevista los cerdos se pesaron, se midieron y se fotografiaron, generándose así un respaldo documental mediante el cual cada animal se asignó a una de tres poblaciones consideradas en el estudio y definidas como cerdo Pelón Mexicano (PPM, $n=65$ ), cerdo Cuino $(\mathrm{PCU}, \mathrm{n}=25)$ y cerdos de cruza indefinida ( $\mathrm{PCl}$, $n=151)$.

Las variables analizadas fueron: peso corporal (Peco); longitud de la cabeza (Loca) que se obtuvo al medir desde la punta del hocico hasta la base de la cabeza; longitud del cuerpo (Locu) que se obtuvo al medir desde la base de la nuca hasta el nacimiento de la cola; circunferencia del pecho (Circu) que correspondió al valor de la circunferencia torácica tomada detrás de la espalda; altura a la cruz (Acruz) que correspondió a la altura del animal medida desde el suelo hasta la cruz; ancho de la pelvis (Anpe) que se midió como la distancia is the estimated value of the sample proportion that will answer the survey in the same way, in this case 0.45 . Survey subject selection was done using the snowball sampling technique; backyard pig owners were identified, the data from the first subject was used to locate the following subject, and this process was repeated until the estimated sample size was attained(7). On the same day the survey was applied to an owner, his/her pigs were weighed, measured and photographed. Each documented animal was assigned to one of three populations of pigs: Mexican hairless ( $M H, n=65)$, Cuino (CU, $n=25$ ) and Undefined cross (UD, $n=151$ ).

Analyzed variables were body weight (BW); head length (HL), measured from the tip of the snout to the base of the head; body length (BL), measured from the base of the neck to the base of the tail; chest girth (CG), which is circumference measured at the thoracic level from the back; height at withers (HW), measured from ground surface to the withers; rump width (RW), measured as the distance between the iliac tuberosities; teat count (TC); dense or sparse hair (HD); presence or absence of tusks (TU); long or short snout (ST); upright or floppy ears (ER); and calm or restless temperament (TM). While body measurements were being taken, temperament was classified into one of two categories: moderately manageable or difficult to handle. Three zoometric indices were also calculated: proportionality index $(\mathrm{PI})=(\mathrm{HW} * 100) / \mathrm{BL} ;$ body index $(\mathrm{BI})=(\mathrm{BL} * 100) / \mathrm{HW}$; and relative weight index $(\mathrm{RWI})=(\mathrm{BW} * 100) / \mathrm{HW}$.

Data was analyzed with the general least squares method using the GLM and GENMOD procedures in the SAS statistic package ${ }^{(8)}$. The GLM procedure was applied to the variables BW, HL, BL, CG, HW, CW, RW, TC, Pl, Bl and RWI under the assumption of a normal probability distribution. The GENMOD procedure was applied to the variables HD, TU, ST, ER and TM under the assumption of a binomial probability distribution. The variation coefficient (VC) was calculated for all variables using the 
entre las dos tuberosidades ileacas; número de pezones (Nupe); pelo denso o escaso (Cape); presencia o ausencia de colmillos (Colm); hocico corto o largo (Hoc); orejas erguidas o no erguidas (Posio) y temperamento tranquilo o inquieto (Tem). El temperamento se clasificó al momento de las mediciones corporales de acuerdo a dos categorías de comportamiento: moderadamente manejable o difícil de manejar. Adicionalmente se calcularon los índices zoométricos siguientes: índice de proporcionalidad $(I P)=($ Acruz $* 100) /$ Locu; índice corporal (IC) $=($ Locu $* 100) /$ Acruz e índice de peso relativo $($ IPR $)=($ Peco $* 100) /$ Acruz.

La información se analizó con el método de cuadrados mínimos generales utilizando los procedimientos GLM y GENMOD del paquete estadístico SAS(8). El procedimiento GLM se utilizó para el análisis de las variables bajo el supuesto de distribución probabilística normal (Peco, Loca, Locu, Circu, Acruz, Anpe, Nupe, IP, IC e IPR) y el procedimiento GENMOD para el análisis de las variables bajo el supuesto de distribución probabilística Binomial (Cape, Colm, Hoc, Posio y Tem). Para todas las variables se estimó el coeficiente de variación de acuerdo a la formula siguiente: Coeficiente de variación= (desviación estándar * media) * 100. Para interpretar las medias de cuadrados mínimos (MCM) estimadas con el procedimiento GENMOD se realizó la transformación siguiente: $\mathrm{e}^{(\mathrm{MCM})}$ / $((1+e) M C M)(9)$. Para todas las variables los modelos estadísticos finales incluyeron los efectos fijos de Estado (18 niveles) y población (3 niveles). No se incluyeron otros efectos fijos, como sexo o edad, en los modelos finales por no contar con la información respectiva.

El modelo estadístico básico utilizado fue el siguiente:

$$
Y_{i j k}=\mu+E_{i}+P_{j}+e_{i j k}
$$

Donde: $\mu=$ media general; $E_{i=}$ efecto fijo del $\mathrm{i}$-ésimo estado $(\mathrm{i}=1,2, \ldots, 18) ; \mathrm{P}_{\mathrm{j}}$ e efecto fijo de la j-ésima población ( $j=1,2$ y 3); $e_{i j k l m=}$ efecto residual distribuido $\mathrm{NI}\left(0, \sigma^{2} \mathrm{e}\right) ; 0$ distribuido $B(n, p)$. formula: $\mathrm{VC}=$ (standard deviation $\div$ mean $) *$ 100. The least squares means (LSM) estimated with GENMOD were transformed as follows: $\mathrm{e}^{(\mathrm{LSM})} /((1+\mathrm{e}) \mathrm{LSM})(9)$. The final statistical models for all variables included the fixed effects of state (18 levels) and population (3 levels). Other fixed effects such as sex or age were not included due to lack of data.

The basic statistical model was:

$$
Y_{i j k}=\mu+E_{i}+P_{j}+e_{i j k}
$$

where: $\mu=$ general mean; $E_{i}=$ fixed effect of the $i$-th state $(i=1,2, \ldots, 18) ; P_{j}=$ fixed effect of the $j$-th population $(j=1,2$ and 3$) ; e_{i j k l m=}$ distributed residual effect $\mathrm{NI}\left(0, \sigma^{2}{ }_{e}\right)$; or distributed $B(n, p)$.

\section{RESULTS AND DISCUSSION}

Variation coefficients (VC), least squares means (LSM) and standard errors are shown in Table 1. The effect of State was significant $(P<0.01)$ for all variables whereas population affected $(\mathrm{P}<0.05) \mathrm{BW}, \mathrm{BL}, \mathrm{CG}, \mathrm{HW}, \mathrm{RW}, \mathrm{TU}, \mathrm{TM}, \mathrm{PI}, \mathrm{BI}$ and RWI.

\section{Morphometric variability}

Based on the estimated VC values, BW exhibited the least variation (18.8\%) and CG the most (27.8\%). Other variables had intermediate VC values, such as HL (24.9\%), CG (23.5\%), BL (23.3\%), TC (22.8\%) and HW (21.2\%). Other studies have reported estimated VC values lower than those observed here. In a study of morphometry in native Cuino pigs in Nayarit, Mexico, the VC values were $7.56 \%$ for TC, $8.46 \%$ for CG and $11.79 \%$ for BL(3). A study done in Venezuela found VC values of $7.62 \%$ for HW, $9.26 \%$ for RW, $9.78 \%$ for CG, and $10.9 \%$ for $\mathrm{HL}(10)$. In a zoometric characterization of native pigs done in Columbia, estimated VC values were $10.36 \%$ for HW, $11.84 \%$ for CG and $12.76 \%$ for RW(5). Values reported for the Pampa Rocha breed, from Uruguay, agree with the previous values: $5 \%$ for HW; $6 \%$ for BL; $10 \%$ for HL; $11 \%$ for 


\section{RESULTADOS Y DISCUSIÓN}

En el Cuadro 1 se muestran los coeficientes de variación (CV), las medias de cuadrados mínimos y los errores estándar para las diferentes variables e índices evaluados. El efecto de Estado fue importante $(\mathrm{P}<0.01)$ para todas las variables analizadas, mientras que población influyó significativamente $(\mathrm{P}<0.05)$ sobre Peco, Locu, Circu, Acruz, Cape, Colm, Tem IP, IC e IPR.

Variabilidad morfométrica

Los CV estimados en el presente estudio señalan a Peco y Anpe como las características con menor y mayor variación (CV de 18.8 y 27.8 \%,
RW; and $19 \%$ for live weight(11). Another study done with the same breed found VC values of $5.90 \%$ for HW in males and $6.92 \%$ in females, $11.90 \%$ for RW in males and $11.06 \%$ in females; and $8.88 \%$ for live weight in females and $25.36 \%$ in males(12). In contrast, VC values for native pigs in Guatemala have been reported to be lower in males than in females: 11.09 vs $15.06 \%$ for CG; 15.35 vs $16.72 \%$ for RW; 16.29 vs $19.16 \%$ for $\mathrm{HL}$; and 17.68 vs $23.74 \%$ for live weight(13).

The VC values in the present study exhibited greater morphological variability than other native pig populations in Latin America(3,10-13). This variability can be attributed to differences

Cuadro 1. Coeficientes de variación (VC), medias de cuadrados mínimos y errores estándar para variables morfométricas de cerdo Pelón Mexicano $(\mathrm{MH})$, cerdo Cuino (CU) y cerdos de cruza indefinida (UD) en áreas rurales de México

Table 1. Least squares means ( \pm standard error) and variation coefficients $(\mathrm{VC})$ for morphometric variables in Mexican hairless (MH), Cuino (CU) and undefined cross (UD) pigs from rural areas in Mexico

\begin{tabular}{llccc}
\hline Variable & $\mathrm{MH}$ & $\mathrm{CU}$ & $\mathrm{UD}$ & VC \\
\hline $\mathrm{BW}$ & $48.06 \pm 6.17^{\mathrm{a}}$ & $35.93 \pm 3.04^{\mathrm{b}}$ & $61.11 \pm 7.42^{\mathrm{a}}$ & 18.8 \\
$\mathrm{HL}$ & $27.22 \pm 1.4^{\mathrm{a}}$ & $25.36 \pm 0.7^{\mathrm{a}}$ & $25.20 \pm 1.7^{\mathrm{a}}$ & 24.9 \\
$\mathrm{BL}$ & $77.81 \pm 3.6^{\mathrm{ab}}$ & $69.56 \pm 2.0^{\mathrm{a}}$ & $88.52 \pm 4.9^{\mathrm{b}}$ & 23.3 \\
$\mathrm{CG}$ & $80.55 \pm 3.9^{\mathrm{ab}}$ & $71.72 \pm 2.2^{\mathrm{a}}$ & $93.23 \pm 5.3^{\mathrm{b}}$ & 23.5 \\
$\mathrm{HW}$ & $56.88 \pm 2.4^{\mathrm{ab}}$ & $51.26 \pm 1.3^{\mathrm{a}}$ & $60.32 \pm 3.3^{\mathrm{b}}$ & 21.2 \\
$\mathrm{RW}$ & $20.12 \pm 1.0^{\mathrm{a}}$ & $19.31 \pm 0.6^{\mathrm{a}}$ & $21.45 \pm 1.4^{\mathrm{a}}$ & 27.8 \\
TC & $10.47 \pm 0.55^{\mathrm{a}}$ & $9.65 \pm 0.28^{\mathrm{a}}$ & $10.93 \pm 0.66^{\mathrm{a}}$ & 22.8 \\
$\mathrm{HD}$ & $57 \pm 4^{\mathrm{a}}$ & $71 \pm 19^{\mathrm{b}}$ & $62 \pm 34^{\mathrm{a}}$ & - \\
TU & $68 \pm 31^{\mathrm{ab}}$ & $70 \pm 14 \mathrm{a}$ & $61 \pm 27^{\mathrm{b}}$ & - \\
ST & $69 \pm 36^{\mathrm{a}}$ & $65 \pm 10^{\mathrm{a}}$ & $65 \pm 27 \mathrm{a}$ & - \\
ER & $62 \pm 28^{\mathrm{a}}$ & $61 \pm 10^{\mathrm{a}}$ & $56 \pm 32^{\mathrm{a}}$ & - \\
TM & $65 \pm 30^{\mathrm{a}}$ & $56 \pm 12^{\mathrm{b}}$ & $62 \pm 3^{\mathrm{a}}$ & - \\
PI & $76.03 \pm 2.09 \mathrm{a}$ & $74.31 \pm 1.16^{\mathrm{ab}}$ & $69.04 \pm 2.83^{\mathrm{b}}$ & 13.0 \\
BI & $35.94 \pm 4.31^{\mathrm{a}}$ & $37.29 \pm 2.39^{\mathrm{a}}$ & $51.02 \pm 5.82^{\mathrm{b}}$ & 14.6 \\
RWI & $79.65 \pm 8.0^{\mathrm{ab}}$ & $67.60 \pm 3.94 \mathrm{a}$ & $97.66 \pm 9.64^{\mathrm{b}}$ & 45.8 \\
\hline
\end{tabular}

$\mathrm{BW}=$ body weight $(\mathrm{kg}) ; \mathrm{HL}=$ head length $(\mathrm{cm}) ; \mathrm{BL}=$ body length $(\mathrm{cm}) ; \mathrm{CG}=$ chest girth $(\mathrm{cm}) ; \mathrm{HW}=$ height at withers $(\mathrm{cm})$; RW= rump width $(\mathrm{cm}) ; \mathrm{TC}=$ teat count; $\mathrm{HD}=$ hair density $(\%)$; $\mathrm{TU}=$ presence or absence of tusks (\%); ST= long or short snout (\%); $\mathrm{ER}=$ upright or floppy ears (\%); $\mathrm{TM}=\mathrm{calm}$ or restless temperament $(\%) ; \mathrm{Pl}=$ proportionality index $=\left(\mathrm{HW}{ }^{*} 100\right) / \mathrm{BL} ; \mathrm{Bl}=$ body index $=\left(\mathrm{BL}{ }^{*} 100\right) / \mathrm{HW} ; \mathrm{RWI}=$ relative weight index $=(\mathrm{BW} * 100) / \mathrm{HW}$.

abc Different letter superscripts in the same row indicate difference $(P<0.05)$. 
respectivamente). Coeficientes de variación con valores intermedios fueron estimados para Loca $(24.9 \%)$, Circu (23.5 \%), Locu (23.3\%), Nupe $(22.8 \%)$ y Acruz $(21.2 \%)$. En contraste con estos resultados, diversos autores han publicado CV más bajos que los estimados en el presente trabajo. Así, un estudio en que se evaluó la morfometría de una población de cerdos criollos cuinos en Nayarit, México, estableció CV de 7.56, 8.46 y $11.79 \%$ para número de pezones, perímetro torácico y longitud corporal(3). En otra investigación sobre la morfología del cerdo criollo realizada en Venezuela se encontraron CV de 7.62, 9.26, 9.78 y $10.9 \%$ para las variables alzada a la cruz, ancho de grupa, perímetro torácico y longitud de la cabeza(10). De manera similar, un estudio realizado en Colombia sobre caracterización zoométrica de cerdos criollos estimó CV de 10.64, 11.84 y $12.76 \%$ para alzada a la cruz, perímetro torácico y ancho de la grupa, respectivamente(5). Coincidiendo con lo anterior, a partir de caracterizaciones zoométricas realizadas en poblaciones de cerdos de la raza local Pampa Rocha en Uruguay, se estimaron CV de 5, 6, 10, 11 y $19 \%$ para alzada a la cruz, longitud corporal, longitud de la cabeza, anchura de la grupa y peso vivo(11), y CV de 5.90 y $6.92 \%$ en machos y hembras para alzada a la cruz; de 11.90 y $11.06 \%$ en machos y hembras para ancho de grupa, y de 8.88 y $25.36 \%$ en machos y hembras para peso vivo(12). Por otro lado, un estudio realizado con cerdos criollos en Guatemala mostró valores menores de CV para los machos comparados con los de las hembras, de 11.09 y $15.06 \%$ para perímetro torácico, 15.35 y $16.72 \%$ para ancho de la grupa, 16.29 y $19.16 \%$ para longitud de la cabeza, y 17.68 y $23.74 \%$ para peso vivo(13).

Los coeficientes de variación del presente trabajo señalan que, en general, la población evaluada presentó una mayor variabilidad morfológica en relación a otras poblaciones de cerdos criollos de América Latina(3,10-13). Esta variabilidad morfológica puede atribuirse a diferencias en los sistemas de manejo y ambientes en los que se desarrollaron las subpoblaciones así como a in the management systems and environments in which the subpopulations are grown as well as genetic diversity within subpopulations.

Among the three zoometric indices calculated in the present study, the smallest data dispersion was in the $\mathrm{PI}(\mathrm{VC}=13.0 \%)$, suggesting the presence of a homogeneous breed pattern in the evaluated populations. In contrast, the VC values for the RWI (45.8\%) and BI (14.6\%) suggest that data comes from populations with heterogeneous production focuses. These results support the use of zoometric indices as useful tools in breed and functional evaluations(14). Similar PI (12 \%) and BI (10 \%) values have been reported in a morphostructural study of a local pig population in Corrientes Province, Argentina(15). Lower VC values (7.04 \% for PI; $7.74 \%$ for $\mathrm{BI}$ ) were estimated for a native pig population in Venezuela(10). Similar VC values for the $\mathrm{Bl}$ were reported for male $(7.89 \%)$ and female $(8.04 \%)$ pigs in Guatemala, while the corresponding $\mathrm{PI}$ values were of $12.72 \%$ in females and $22.39 \%$ in males(13). Much higher values (44.87 to $87.09 \%$ ) have been reported for the compactness index in a morphometric evaluation comparing local pig populations in different municipalities of Brazil(16).

\section{Quantitative variables}

The LSM for BW, BL, CG and HW variables in Table 1 show that, in general, morphometry was similar between the $\mathrm{MH}$ and UD populations, which differed from the CU population. In addition, the $\mathrm{CU}$ population had lower weight and size than the $\mathrm{MH}$ and UD populations.

Average index values similar to those of the $\mathrm{MH}$ and CU populations have been reported for native pigs in indigenous communities in the state of Chiapas, Mexico $(52.63 \pm 4.81 \mathrm{~cm}$ for HW; $46.57 \pm 13.35 \mathrm{~kg}$ for live weight; and $86.74 \pm 10.61$ for $\mathrm{CG}$ )(2). Similar values have also been reported for native pigs in low input production systems in Venezuela $(59.51 \pm 4.71$ $\mathrm{cm}$ for HW; $17.07 \pm 1.57 \mathrm{~cm}$ for RW; $84.85 \pm$ $8.30 \mathrm{~cm}$ for $\mathrm{CG})(10)$, and Colombia (56.41 \pm 
la diversidad genética existente entre las mismas.

En relación a los índices zoométricos estimados en el presente estudio, la menor dispersión de los datos se observó en el índice de proporcionalidad ( $\mathrm{CV}=13.0 \%$ ) lo cual sugiriere que las poblaciones evaluadas presentaron un patrón racial homogéneo. Por otro lado, los CV para índice de peso relativo (45.8\%) e índice corporal (14.6\%) sugieren poblaciones heterogéneas en cuanto la orientación productiva de los animales. Lo anterior de acuerdo a la clasificación de los índices zoométricos como elementos útiles para la evaluación racial y funcional de los animales(14). Valores similares de CV para índice de proporcionalidad (12\%) e índice corporal (10 \%) se reportaron en un estudio morfoestructural realizado en una población local de cerdos en la Provincia de Corrientes, Argentina(15). Por otro lado, CV menores fueron estimados en una evaluación de cerdos criollos realizada en Venezuela con valores de 7.04 y $7.74 \%$ para índice de proporcionalidad e índice corporal, respectivamente $(10)$. Coincidiendo con lo anterior, un estudio sobre caracterización de cerdos criollos realizado en Guatemala determinó CV de 7.89 y $8.04 \%$ para índice corporal de machos y hembras, respectivamente, mientras que para índice de proporcionalidad fueron de $12.72 \%$ (hembras) y $22.39 \%$ (machos)(13). En contraste con los resultados previos, valores altos de dispersión fueron estimados para índice de compacidad en una evaluación morfométrica en la que se compararon poblaciones locales de cerdos provenientes de diferentes municipalidades en Brasil, con CV que estuvieron entre 44.87 y $87.09 \%(16)$.

\section{Variables cuantitativas}

Las MMC del Cuadro 1 para las variables Peco, Locu, Circu y Acruz muestran que, en general, las poblaciones PPM y $\mathrm{PCl}$ son similares en morfometría, siendo diferentes ambas de la población PCU. Los resultados también indican que la población PCU es de menor peso y talla
$6.0 \mathrm{~cm}$ for HW; $17.29 \pm 2.21 \mathrm{~cm}$ for RW; 85.66 $\pm 10.14 \mathrm{~cm}$ for $\mathrm{CG})^{(5)}$. For the same traits, lower values were reported for native pigs grown in rural communities in Guatemala ( $47 \pm 5.8$ for HW; $15 \pm 2.5$ for RW; $65 \pm 7.2 \mathrm{~cm}$ for CG; and $45.52 \mathrm{~kg}$ for live weight)(13).

In contrast to the present average values for the $\mathrm{MH}$ and $\mathrm{CU}$ populations, higher values have been reported for other native pig populations. Mexican hairless pig populations in the state of Nayarit, Mexico, had clearly higher values in confinement (68.34 \pm 1.39 for HW; $102.53 \pm$ 1.57 for CG; and $82.10 \pm 3.01$ for BL) and grazing systems (68.14 \pm 1.84 for HW; 102.66 \pm 2.08 for CG; and $79.52 \pm 4.0$ for $\mathrm{BL}$ )(17). Live weight was also higher $(57.42 \mathrm{~kg})$ in these $\mathrm{MH}$ populations in intensive weight gain systems at $175 \mathrm{~d}$ of age (18). Similarly to those studies above zoometric data for local Pampa Rocha pig populations have been also generated in Uruguay $(72.7 \pm 3.55,74.97 \pm 5.18$ and 82.33 $\pm 4.85 \mathrm{~cm}$ for $\mathrm{HW} ; 27.2 \pm 2.89,26.97 \pm 2.98$ and $25.66 \pm 3.05 \mathrm{~cm}$ for RW; $103.68 \pm 6.69$, $102.02 \pm 6.95$ and $99 \pm 9.16 \mathrm{~cm}$ for $\mathrm{BL}$; and $137 \pm 26.2,148.6 \pm 37.69$ and $173.66 \pm 15.41$ for live weight) $(11,12)$. Body weight higher than the observed in the present study for the $\mathrm{MH}$ and $\mathrm{CU}$ populations have been estimated for local pigs sampled from farms in Brazil (live weight $=54.40 \mathrm{~kg})(16)$, and native pigs from rural areas in Argentina (live weight $=60.47 \pm$ $10 \mathrm{~kg})^{(15)}$. However, in the latter study averages similar to those for the present $\mathrm{MH}$ population were reported for HW $(56.09 \pm 3.49 \mathrm{~cm})$, BL $(75.82 \pm 4.96 \mathrm{~cm})$, and RW $(17.26 \pm 1.54 \mathrm{~cm})$. Some morphometric values reported for Cuino native pigs in Nayarit were lower than those observed in the present CU population ( $\mathrm{HW}=$ $47.60 \pm 4.14 \mathrm{~cm} ; \mathrm{BL}=62.25 \pm 7.69 \mathrm{~cm}$ ) while others were higher $(\mathrm{CG}=87.28 \pm 7.39 \mathrm{~cm}$; live weight $=43.84 \pm 10.55 \mathrm{~kg})^{(3)}$.

\section{Qualitative variables}

The LSM for HD (71 $\pm 19 \%)$, TU (70 $\pm 14 \%)$ and TM $(56 \pm 12 \%)$ indicate that the CU population had greater hair density, more tusk 
comparada con las poblaciones PPM y PCl (Peco de $48.06 \pm 6.17,35.93 \pm 3.04$ y $61.11 \pm 7.42$ $\mathrm{kg}$, Acruz de $56.88 \pm 2.45,51.26 \pm 1.36 \mathrm{y}$ $60.32 \pm 3.31 \mathrm{~cm}$ y Circu de $80.55 \pm 3.98$, $71.72 \pm 2.20$ y $93.23 \pm 5.37 \mathrm{~cm}$ para PPM, $\mathrm{PCU}$ y $\mathrm{PCl}$, respectivamente.

Promedios similares a los de PPM y PCU del presente estudio se estimaron para cerdos autóctonos en comunidades indígenas de Chiapas, México, con medias de $52.63 \pm 4.81$ $\mathrm{cm}, 46.57 \pm 13.35 \mathrm{~kg}$ y $86.74 \pm 10.61 \mathrm{~cm}$ para alzada a la cruz, peso vivo y perímetro torácico, respectivamente(2). Asimismo, estudios realizados en dos poblaciones de cerdos criollos determinaron promedios de $59.51 \pm 4.71 \mathrm{y}$ $56.41 \pm 6.0 \mathrm{~cm}$ para alzada a la cruz, $17.07 \pm$ 1.57 y $17.29 \pm 2.21 \mathrm{~cm}$ para ancho de la grupa y $84.85 \pm 8.30$ y $85.66 \pm 10.14 \mathrm{~cm}$ para perímetro torácico de cerdos criollos mantenidos en sistemas de producción de bajos insumos en Venezuela y Colombia $(5,10$,$) . Para las mismas$ características, valores más bajos fueron reportados en cerdos criollos desarrollados en comunidades rurales de Guatemala con promedios de $47 \pm 5.8,15 \pm 2.5,65 \pm 7.2 \mathrm{~cm}$ y $45.52 \mathrm{~kg}$ para alzada a la cruz, ancho de la grupa, perímetro torácico y peso vivo, respectivamente(14).

En contraste a los promedios para PPM y PCU del presente estudio, valores más altos han sido publicados para diferentes poblaciones de cerdos criollos. Así, en poblaciones de cerdo Pelón Mexicano en Nayarit, México se estimaron para cerdos en confinamiento y pastoreo promedios de $68.34 \pm 1.39$ y $68.14 \pm 1.84 \mathrm{~cm}$ para alzada a la cruz, de $102.53 \pm 1.57$ y $102.66 \pm 2.08 \mathrm{~cm}$ para perímetro torácico y de $82.10 \pm 3.01$ y $79.52 \pm 4.0 \mathrm{~cm}$ para longitud de la espalda(17); y peso vivo de $57.42 \mathrm{~kg}$ a los 175 días de edad en engorda intensiva(18). Coincidiendo con lo anterior, estudios sobre caracterizaciones zoométricas con poblaciones locales de cerdos de la raza Pampa Rocha en Uruguay reportaron promedios de $72.7 \pm 3.55$, $74.97 \pm 5.18$ y $82.33 \pm 4.85 \mathrm{~cm}$ para alzada a la cruz, de $27.2 \pm 2.89,26.97 \pm 2.98$ y 25.66 frequency and more animals with a restless temperament. Hair density and temperament have been evaluated in different native pig populations. For example, a study of native pigs in Chocó department, Colombia, found that $85.29 \%$ of the sampled population had hair(5), and in a phaneroptical characterization of native pigs in rural communities in Venezuela $63.24 \%$ of the sample had abundant hair(13). All the native pigs sampled in one study in rural areas of Argentina were found to have hair(15). In a study of native pigs in indigenous communities in Chiapas State, Mexico, the animals were found to have large, thick bristles concentrated on the upper portion of the neck and around the withers (2). In contrast to the present results, a morphometric study of native pigs in Nayarit, Mexico, reported that the sampled Cuino pigs exhibited a calmer temperament than the more aggressive Mexican Hairless pigs(17). A more aggressive temperament has been reported for pigs sampled at different farms in northeast Brazil(16).

\section{CONCLUSIONS AND IMPLICATIONS}

Overall, the present morphometric results indicate greater variability in the three evaluated populations than other native pig populations in Latin America. The observed morphometric variability can be attributed to differences in the management systems and environments in which the three populations were grown, as well as genetic diversity among them. Morphometrically, the $\mathrm{MH}$ and UD populations were similar while both differed from the CU population. The CU population exhibited higher hair density, lower weight and size, and a more restless temperament when compared to the $\mathrm{MH}$ and UD populations. It is important to characterize the backyard pig populations to design strategies that contribute to the conservation and efficient use of these genetic resources.

End of english version 
$\pm 3.05 \mathrm{~cm}$ para ancho de la grupa, de 103.68 $\pm 6.69,102.02 \pm 6.95$ y $99 \pm 9.16 \mathrm{~cm}$ para longitud corporal y de $137 \pm 26.2,148.6 \pm$ 37.69 y $173.66 \pm 15.41 \mathrm{~kg}$ para peso vivo $(11,12)$. Mayores pesos corporales a los de PPM y PCU también fueron estimados en cerdos locales muestreados en diferentes granjas porcinas de Brasil (peso vivo de $54.40 \mathrm{~kg}^{(16)}$ y en cerdos criollos de áreas rurales de Argentina con peso vivo de $60.47 \pm 10 \mathrm{~kg}$ y perímetro torácico de $94.29 \pm 5.83 \mathrm{~cm}(15)$, cabe señalar que en esta última población se estimaron promedios similares a los de PPM para alzada a la cruz $(56.09 \pm 3.49 \mathrm{~cm})$, largo del cuerpo $(75.82 \pm$ $4.96 \mathrm{~cm})$ y ancho de grupa $(17.26 \pm 1.54 \mathrm{~cm})$. Por otro lado, un estudio realizado en Nayarit, México sobre cerdos Criollos Cuinos reportó valores menores que los de PCU para altura a la cruz $(47.60 \pm 4.14 \mathrm{~cm})$ y largo del cuerpo $(62.25 \pm 7.69 \mathrm{~cm})$, pero mayores para perímetro torácico $(87.28 \pm 7.39 \mathrm{~cm})$ y peso vivo $(43.84$ $\pm 10.55 \mathrm{~kg})^{(3)}$.

\section{Variables cualitativas}

Las MMC del Cuadro 1 para las variables Cape, Colm y Tem señalan a PCU como la población con mayor densidad de pelo, mayor presencia de colmillos y menor porcentaje de animales con temperamento tranquilo mostrando promedios de $71 \pm 19,70 \pm 14$ y $56 \pm 12 \%$ para Cape, Colm y Tem, respectivamente. Cabe mencionar que la presencia o ausencia de pelo y el tipo de temperamento son características cualitativas que se han evaluado en diferentes poblaciones de cerdos criollos. Así, en un estudio sobre el cerdo criollo del Chocó en Colombia se encontró que el $85.29 \%$ de la población muestreada tenía pelaje(5), mientras que una caracterización faneróptica de cerdos criollos en comunidades rurales de Venezuela reportó 63.24 y $36.76 \%$ de animales con presencia abundante y escasa de pelo, respectivamente(13). De igual manera, la presencia de pelo fue reportada en el $100 \%$ de una población de cerdos criollos muestreada en áreas rurales de Argentina(15), mientras que un estudio realizado con cerdos autóctonos de comunidades indígenas en
Chiapas, México encontró que estos animales mostraron el cuerpo cubierto de grandes cerdas gruesas más abundantes en la parte superior del cuello y en la región de la cruz(2). Por otro lado y en contraste con los resultados del presente trabajo, un estudio realizado sobre caracterización morfométrica de cerdos criollos en Nayarit, México reportó a los cerdos Cuinos como animales de temperamento tranquilo comparados con el temperamento agresivo detectado en los animales de la raza Pelón Mexicano(17). De igual manera, en una población local de cerdos ubicada en diferentes granjas del Noreste de Brasil se reportó un temperamento agresivo entre los animales muestreados(16).

\section{CONCLUSIONES E IMPLICACIONES}

En general, la información revisada sobre variabilidad morfométrica señala mayor variabilidad de las tres poblaciones evaluadas en relación a otras poblaciones de cerdos criollos de América Latina. La variabilidad morfométrica detectada puede atribuirse a diferencias en los sistemas de manejo y ambientes en los que se desarrollaron las tres poblaciones y a la diversidad genética existente entre las mismas. Las poblaciones PPM y PCl fueron similares en morfometría siendo diferentes ambas a la población PCU. La población PCU mostró mayor densidad de pelo, menor peso, menor talla, y temperamento más inquieto comparada con las poblaciones PPM y $\mathrm{PCl}$. Es importante caracterizar a las poblaciones de cerdos de traspatio para diseñar estrategias que contribuyan a la conservación y el uso eficiente de estos recursos genéticos.

\section{LITERATURA CITADA}

1. Góngora GS, Ricahards M, Berdugo RJ. Análisis económico y social de la porcicultura rural de traspatio de los municipios de Mérida y Umán del estado de Yucatán. Tec Pecu Méx 1986; 50: 115-126.

2. Galdámez FD, Perezgrovas GR. Las mujeres Tzeltales de Aguacatenango y el cuidado de sus cerdos autóctonos. 
Instituto de Estudios Indígenas. Cría de cerdos autóctonos en comunidades indígenas. México. Universidad Autónoma de Chiapas. 2007.

3. Lemus-Flores C, Alonso-Morales R, Herrera-Haro J G, AlonsoSpilsbury M, Ramirez-Necoechea R, Mota-Rojas D. Growth, morphometry and reproductive performance of Creole Cuino pigs in México. J Anim Vet Adv 2005;4:(10):855-858.

4. Hurtado E, González C, Vecchionacce H. Estudio morfológico del cerdo criollo del estado de Apure, Venezuela. Zoot Trop 2005;23(1): 17-26.

5. Arredondo JV, Muñoz JE, Arenas LE, Pacheco E, Álvarez LA. Caracterización zoométrica de cerdos Criollos en el Departamento del Chocó-Colombia. AICA 2011; 1:57-59.

6. FAO. Realización de encuestas y seguimiento de los recursos zoogenéticos. Directrices FAO: Producción y sanidad animal. No. 7. Roma. 2012.

7. García C, Almanera J. Determinación del tamaño de muestra en variables cualitativas en las que se desconoce el valor del parámetro. Med Clin (Barc) 1999;112:797-798.

8. SAS. SAS User's Guide: Statistics (version 4.2 ed.). Cary NC, USA: SAS Inst. Inc. 2001.

9. Nelder JA, Wedderburn RWM. Generalized linear models. J Royal Statist Soc 1972;135:370-384.

10. Hurtado E, González C, Vecchionacce H. Estudio morfológico del cerdo criollo del estado de Apure, Venezuela. Zoot Trop 2005;23(1): 17-26.

11. Llambi S, Montenegro MC, Castro G, Barlocco N, Gagliardi $\mathrm{R}$, Vadell A. Marcadores de ADN y caracterización fenotípica en cerdos Pampa Rocha (Uruguay). Proyecto CSIC-UDELAR. AlCA 2011; 1:82-85.

12. Castro G, Montenegro M, Barlocco N, Vadell A, Gagliardi R, Llambí S. Caracterización zoométrica en el cerdo Pampa Rocha de Uruguay (descriptiva primaria). AICA 2012;2:8386.

13. Lorenzo M, Jáuregui J, Vásquez Ch. Caracterización del cerdo criollo de la región CHO'RTI' del Departamento de Chiquimula, Guatemala. AICA 2012;2:103-108.

14. Revidatti MA. Caracterización de cerdos criollos del Nordeste Argentino [tesis doctoral]. Córdoba, Andalucía, España: Universidad de Córdoba; 2009.

15. Revidatti MA, Delgado-Bermejo JV, Capellari A, Prieto PN. Estudio morfoestructural preliminar de una población porcina en la Provincia de Corrientes. Argentina. Arch Zootec 2005; 54:227-232.

16. Silva FOL, Pimenta FEC, Silva LPG, Pereira WE, Oliveira RJ F, Delgado JV, Sereno JRB. Body morphometry of local pigs of Curimataú Paraibano, Characterization of factors. Rev Comput Prod Porcina 2010;17:(3): 197-202.

17. Becerril HM, Lemus FC. Morfometría del Cerdo Criollo. En: Lemus FC, Alonso SML. El Cerdo Pelón Mexicano y otros cerdos criollos. México: Universidad Autónoma de Nayarit. 2005: 106-124.

18. Lemus FC, Becerril HM, Mota RD. Nutrición y crecimiento. En: Lemus FC, Alonso SML. El Cerdo Pelón Mexicano y otros cerdos criollos. México: Universidad Autónoma de Nayarit; 2005: 125-151. 